\title{
Dystocia in goats, causes and treatment
}

\author{
S.O. Hussain N.W. Zaid \\ Coll.Vet. Med./ Unive of Baghdad
}

\begin{abstract}
This study was conducted on 40 goats suffering from dystocia in Al-Ishakey station to the north of Baghdad. Their age ranged between (1-2.5) years. After careful clinical examination the females classified to three groups according to the causes of dystocia and treatment methods employed to relief the dystocia:

1- The first group composed of (20) goats suffering from dystocia due to lateral deviation of head and neck, this group was treated by mutation and forced extraction to relief the case. All the feti are alive (12 males and 8 females). All these cases are single birth.

2- The second group composed of (12) goats suffering from dystocia due to bilateral shoulder flexion associated with absolute fetal oversize, these cases were treated using partial fetatomy by removing the fore limbs from the shoulder region, all the feti were dead and their sexes were ( 8 males and 4 females). These cases are single birth.

3- The third group (8) goats suffering from dysocia due to relative fetal oversize due to narrow and small pelvis of the dam, the caesarean section was performed to treat these cases and the feti borned are alive (10 males and 6 females) and the cases are twin birth.
\end{abstract}

\section{Introduction:}

Goats are the most widely dispersed meat animals raised for centuries to provide meat, milk, fibers, cashmere and leather (1).Due to their small size, adaptability to harsh environments and availability they are more popular in nations lacking refrigeration, animal management skills and modern transportation (2). The goats considered one of the highly fertile domestic animals (3). There are several reproductive diseases affect the fertility and production causing considerable economic losses (4).Dystocia is one of these problems which cause death in both kids and sometimes the dams in spite of the economic losses, truma and infection due to complication of the case in addition to the treatment coast which may be decrease future fertility (5).The incidence of dystocia formed more than $(50 \%)$ of the reproductive problems (6), some researches reported the incidence

\section{Materials and Methods}

The recent study was conducted on (40) goats suffering from dystocia reared in field station in Al-Ishakey station to the north of Baghdad. The age of the goats ranged from (1-2.5) years according to the dental formula. These cases were diagnosed after careful vaginal examination and then classified to the three different groups according to the causes of about (7\%) in goats (7). The occurrence of dystocia may be either due to maternal or fetal causes (8 and 9). Some researcher investigate the procedures used to treat the dystocia in goats in Iraq $(10,11,12,13,14$ and 15), and in other countries $(1,3,4,8$, $9,16,17,18,19,20,21,22$ and 23).Successful treatment of dystocia depends upon correct diagnosis of the causes of dystocia and when it started (5), these techniques of treatment including manual treatment and traction, fetatomy, hormonal and caesarian section (24).Most of the studies reported in this aspect deals with cases came to the clinic without any information about the past reproductive history or nutrition level, so this study was conducted to evaluate several methods used for treatment of dystocia in goats reared under known environment and good management.

the dystocia and the subjected treatment. The selected procedure was achieved for the purpose:

1- The first group including (20) goats suffering from dystocia due to lateral deviation of the head and neck. Mutation and then forced extraction of the fetus was performed to relief the dystocia. All feti 
were borned alive, the number were (12) male and (8) female.

2- The second group including (12) goats suffering from dystocia due to bilateral shoulder flexion with absolute fetal oversize, these cases subjected to partial fetatomy by removing the two fore limbs from the shoulder region, all the fetuses were dead, there sexes were ( 8 male and 4 female).

3- The third group composed of (8) goats, caesarian section was performed to relief dystocia which is due to relative oversize fetus and small pelvis of the dam. All the fetuses were alive and they were twin birth (10 males and 6 females). The mutation and forced traction was done according to (25), while fetatomy operations were done according to (26). The using of intra uterine tablets, oxytetracycline (Alamycine ${ }^{\circledR}$ ) injected intramuscularly in a dose of $(1 \mathrm{ml} / 10 \mathrm{~kg})$ body weight for three days as well as a single intramuscular injection of (15) international unit of oxytocine after the operations. The caesarian section was performed according to (27), six tablets were placed in the uterine lumen after fetal withdrawing, closure of uterine incision was performed by Lembert sutures using number (1) chromic cat gut. Antibiotic ointment was applied on the closed uterine incision, oxytetracycline (Alamycine $\left.{ }^{\circledR}\right)(1 \mathrm{ml} / 10 \mathrm{~kg})$ was injected intramuscular for three days as well as a single intramuscular injection of (15) international unite of oxytocine administered post operation as mentioned before.

\section{Results}

The study revealed that the different methods which performed for treatment of goats suffering from dystocia were shown in (table 1), the manual correction and traction showed (100\%) response percentage. The general condition and body temperature of the goats was normal with no vaginal discharge or infection. The number of goats which subjected to this method was (20), all of them have lateral deviation of head and neck of the fetus. This case found to constitute the highest percentage of the dystocia cases $(50 \%)$. These cases of dystocia required manual treatment including correction and forced traction for relief. Bilateral shoulder flexion was diagnosed in (12) goats (30\%), and fetatomy operation was the best to treat these cases because the kids were dead (table 1). The caesarian sections were performed in (8) goats suffering from relative oversize fetus and narrowing pelvis of the dam, this study indicate that

treatment with caesarian section represent $(15 \%)$ of total cases (table 1).Table (2) and Diagram (1) showed the recorded number of kids removed by mutation followed by forced extraction, fetatomy and caesarian section, the twining rate were found to be $(20 \%)$ of the pregnancies in goats, while single pregnancy are more common type in the recorded cases $(80 \%)$. The male to female ration were $(62.5 \%)$ males which has been recorded the highest percentage comparing with the $(37.5 \%)$ females (table 3 and Diagram 2).The mortality of delivered kids appeared in (table 4 and Diagram 3) the alive kids in this study showed highest percentage $(75 \%)$ and the dead fetus was $(25 \%)$ in all treated cases.The efficiency of treatment in this study was presented in (table 5 and diagram 4) which depicted that highest successful percentage was the mutation and traction methods.

Table 1: Indication of dystocia in goats

\begin{tabular}{|c|c|c|}
\hline Causes of dystocia & Number of cases & Percentage of cases \\
\hline Lateral head and neck deviation. & 20 & $50 \%$ \\
\hline Bilateral shoulder flexion & 12 & $30 \%$ \\
\hline $\begin{array}{c}\text { Relative oversize fetus with narrowing } \\
\text { pelvic of the dam }\end{array}$ & 8 & $20 \%$ \\
\hline
\end{tabular}


Table 2: Result concerning goats delivery and kid twins

\begin{tabular}{|c|c|c|}
\hline Type of delivery & Number of cases & Percentage of kids \\
\hline Single & 32 & $80 \%$ \\
\hline Twins & 8 & $20 \%$ \\
\hline
\end{tabular}

Table 3: Result concerning the sexes of the fetus

\begin{tabular}{|c|c|c|}
\hline Type of sex & Number of cases & Percentage of sex \\
\hline Male & 30 & $62.5 \%$ \\
\hline Female & 18 & $37.5 \%$ \\
\hline
\end{tabular}

Table 4: Result concerning the sexes of the fetus

\begin{tabular}{|c|c|c|}
\hline Mortality of kids & Number of cases & Percentage of kids \\
\hline Alive & 36 & $75 \%$ \\
\hline Dead & 12 & $25 \%$ \\
\hline
\end{tabular}

Table 5: Efficiency of treatment in goats dystocia

\begin{tabular}{|c|c|c|c|}
\hline Methods used & Number of cases & Responsive cases & Percentage of kids \\
\hline Mutation and traction & 20 & 20 & $50 \%$ \\
\hline Fetatomy & 12 & 12 & $30 \%$ \\
\hline Caesarian section & 8 & 8 & $20 \%$ \\
\hline
\end{tabular}

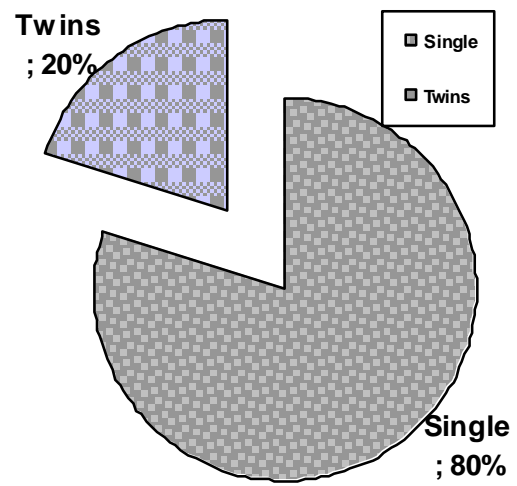

Diagram 1: Result concerning goats delivery and kid twins

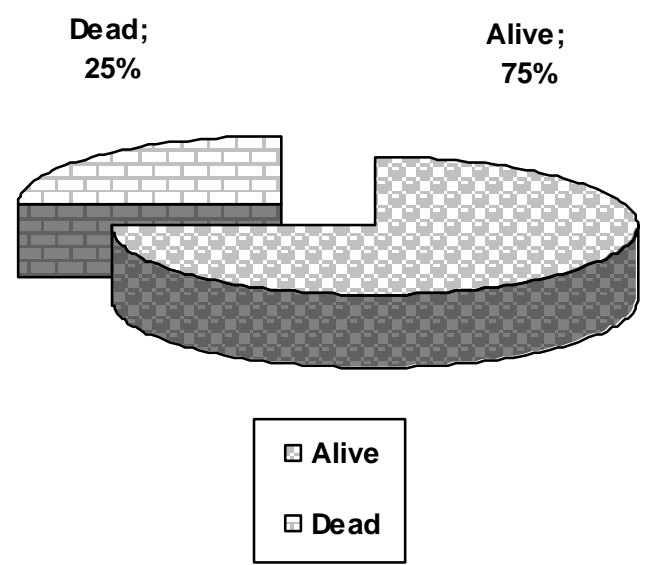

Diagram 3: Result mortality kid

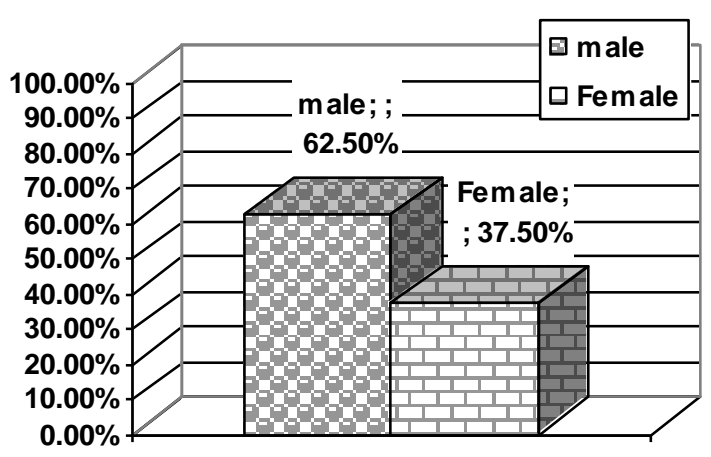

Diagram 2: Result concerning the sex of the fetus

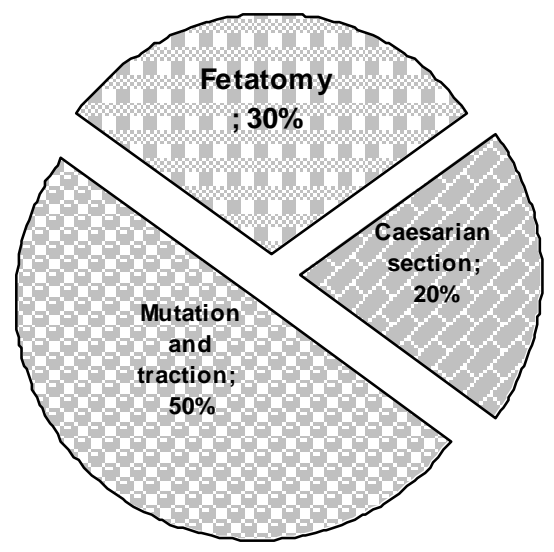

Diagram 4: Efficiency of treatment in goats dystocia 


\section{Discussion:}

There are several factors effect the reproductive performance of the goat lead to decrease their numbers which result from the death of the fetus and the dams. One of the most important factors which lead to great economic losses was the dystocia (28). The incidence of dystocia in goats has been reported about (7\%) from reproductive diseases (7). The causes of dystocia have been reported either due to maternal or fetal in origin (25). In the recent study the fetal causes of dystocia was more common than the maternal causes. This finding was similar to the observation of $(7,8,9,11,14,15,22$ and 28 ) in goats and (24) in the sheep.The finding of this study showed that the goats having single birth are more common and reach $(80 \%)$, while the twins less common (20\%). This result in accordance with (6, 14 and 19) because all of these studies were carried out in females came to clinic, while our study done on field station which applied under a standard role of management (7). The sex of the kids born showed that the goats having male individual more than female, this result inagreement with $(15,22$ and 28). The mortality rate of the kids result from this study similar to the results of $(3,4,13,14$, 15, 24, 29 and 30).Many researchers (6, 8, $9,19,20,23$ and 28) find that deviation of head and neck represent the maximum percentage of causes of dystocia. This is inagreement with the finding of our study.

\section{References}

1. Alford, C. (2008). Meat goat production in Georgia. www.pubs.case.uga.edu. 2/8/2008

2. Odubote, I.K. (2008). Genetic analysis of the reproductive performance of West African Dwarf goats in the humid tropics. www.fao.org. 2/8/2008.

3. McClanahan, S.L. (2008). Fresh doe and newborn kid management. www.freshdoe-mcclanahan.com. 2/6/2008.

4. Jackson, P.G.G. (2008). Handbook of Veterinary

Obstetrics.

www.pighealth.com. 2/8/2008.

5. Aziz, D.M. and Taha, M.B. (1996).

Dystocia in Awassi ewes: causes and 60.
The shoulder flexion found to be one of the major causes of dystocia, this is similar to the studies of $(11,14,19,20,22$ and 23). On the other hand narrowing pelvis of the dam with slight oversize fetus represent an important cause of dystocia, this finding strongly suggested variations in pelvic dimensions among goats (14, 15 and 28).It has been considered that correction and traction of the fetus were the primary safe techniques to relieve the dystocia. This finding similar to $(5,6,8,14,15,19,20$, 23 and 24). The failure of such techniques would direct our attention to other techniques (15), the fetatomy operation were less common never been demonstrated in previous studies in goats. The herein study was the first which used this operations as a successive techniques to relief dystocia especially in dead fetus to avoid exposing the dam to major surgery which decrease the consequences related to post operative follow up of the case (10), this techniques was the second choice of the treatment (31).Success rate of caesarian section was agreed with the finding of $(5$, 10, 13, 15, 16, 20, 24, 32 and 33). This operation showed good prognosis if it performed early when the fetus is alive or freshly dead.It has been concluded that the effectiveness of the types of treatment of delivering kids in dystocia case of goats depend on the type of the dystocia and its causes.

treatments a review. Iraqi Journal of Veterinary Science, 9(1): 1-12.

6. Majeed, A.F. and Taha, M.B. (1989a). Dystocia in local goats in Iraq. Small Ruminant Research, 2: 375-381.

7. Abdul-Rahman, L.Y.; Al-Janabi, A.S. and Asofi, M.K. (2000). Study of some reproduction aspects of the mature local Iraqi goats. The Veterinarian, 10 (1): 47-

8. Kinne, M. (2002a). Maternal causes of dystocia. www.Kine.net 2/8/2008.

9. Thedford, T.R. (2008). Delivery problems in sheep and goats and methods 
of correction. www.lordoats.com. 2/8/2008.

10. Fathalla, M. and Hussain, S.O. (1989). Treatment of ring womb in Shami goats. The Iraqi Journal of Veterinary Medicine, 13: 85-90.

11. Majeed, A.F. and Taha, M.B. (1989b). Preliminary study on treatment of ring womb in Iraqi goats. Animal Reproduction Science. 18: 199-203.

12. Majeed, A.F. and Taha, M.B. (1991). Ring womb in relation to serum calcium, inorganic phosphorus and magnesium in Iraqi goats. Mesopotamia Journal of Agriculture, 23: 65-68.

13. Majeed, A.F.; Taha, M.B. and Azawi, O.I. (1992). Caprine caesarian section. Small Animal Research, 9: 93-97.

14. Majeed, A.F. (1994). Obstetrical problems and their management in Iraqi goats. Small Ruminant Research, 14: 7378.

15. Al-Hamedawi, T.M. and Khammas, D.J. (1994). Treatment of caprine dystocia with special reference to c.s. The Iraqi Journal of Veterinary Medicine, 10 (2): 7986.

16. Philip, P.J.; Nayar, K.N.M.; Nayra, S.R.; Varkey, C.A.; Amma, T.S. and Rajankutty, K. (1985). C. S. in goats - a clinical study. Indian Journal of Veterinary Research, 6: 41-43.

17. Kinne, M. (2002b). Assisting dystocia. www.kinne.net/glinks.htm. 2/8/2008.

18. Selvaraju, M.; Jagatheesan, P.N.R. and Chandrahasan, C. (2006). Dystocia due to hydrocephalus kid in a non - descript goat. Tamilnadu Journal of Veterinary and Animal Science. 2 (6): 255-256.

19. Pelzer, K.D. (2008). Parturition and neonatel care. www.sheepandgoat.com. 2/8/2008.

20. Smith, M.C. (2008). Managing kidding and lambing. www.cornellsheepandgoatsymposium.com . 2/8/2008.
21. Kinne, M. (2008a). Normal birth and recognizing dystocia. www.kinne.net. 2/8/2008.

22. Kinne, M. (2008b). Special problems during pregnancy. www.kinne.net. 2/8/2008.

23. Internet (2008). Parturition. www.compepid.tuskegee.edu. 2/8/2008.

24. Taha, M.B.; Basheer, E.B. and AlKass, Z.M. (2005). Clinical study of dystocia in Awassi ewes (causes and treatments). Iraqi Journal of Veterinary Science, 19 (1): 55-61.

25. Arthur, G.H.; Noakes, D.E.; Pearson, H. and Parkinson, T.J. (1996). Veterinary Reproduction and Obstetrics. $7^{\text {th }}$ ed. WB Saunders company limited.

26. Roberts, S.J. (1986). Veterinary Obstetrics and Genital Diseases (Theriogenology). $3^{\text {rd }}$ ed. Woodstock, Vormont, USA.

27. Hafez, B. and Hafez, E.S.E. (2000). Reproduction in Farm Animals. $7^{\text {th }}$ ed. Lippincott Williams and Wilkins, USA.

28. Abdul-Rahman, L.Y.; Al-Janabi, A.S. and Asofi, M.K. (1999). Causes of dystocia in Iraqi local goats reared in field stations. The Veterinarian, 9 (1): 18-21.

29. Al-Timimi, I.H. (1997). Cesarean section in ewes: causes and treatment. The Veterinarian, 6, 7 (1): 89-94.

30. Majeed, A.F.; Taha, M.B. and Azawi, O.I. (1993). Cesarean section in Iraqi ewes: a case study. Theriogenology, 40: 435-439. 31. Majeed A.F. (2001). A clinical study on dystocia in Iraqi buffaloes. Iraqi Journal of Veterinary Science, 14 (1): 125-128.

32. Al-Sultan, M.A.H. and Majeed, A.F. (1996). Ring womb in Awassi ewes: a review. Iraqi Journal of Veterinary Science, 9 (1): 13-26.

33. Brounts, H.B. (2004). Outcome and subsequent fertility of sheep and goats undergoing cesarean section because of dystocia: 110 cases (1981-2001). Journal of Animal Veterinary Medicine Association, 224 (2): 275-281. 


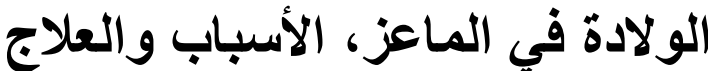

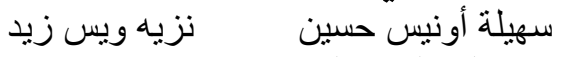
كلية الطب البيطري/ جامعة بغداد
الخلاصة بانة

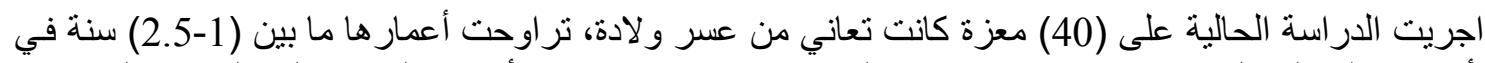

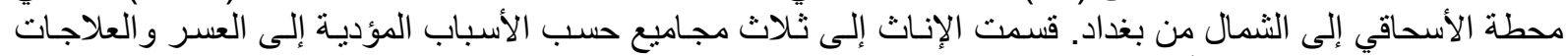

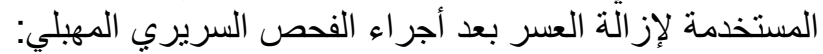

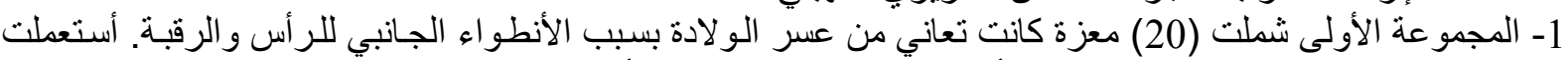

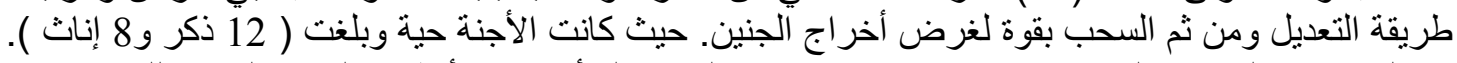

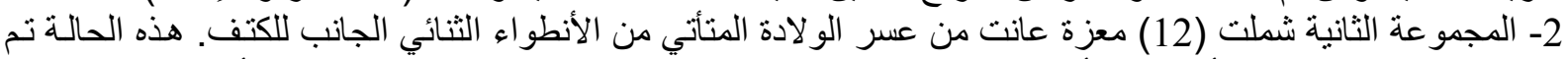

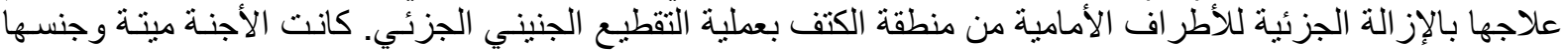

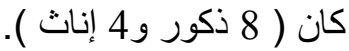

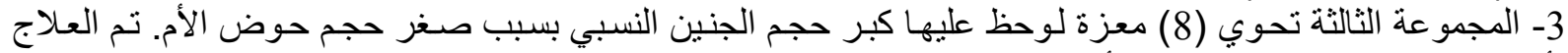
بأجر اء العملية القيصرية وجاءت الأجنة توئمية وحية و عددها (10 ذكور الكور و6 إناث). 